\title{
Bâbur Divanında Öncelemeler ve Öncelemelerde Paralelizm
}

\author{
Foregrounding and Parallelism in Babur's Divan
}

Ö Z E T

Herhangi bir cümle öğesine belli bir amaçla ilk strayı

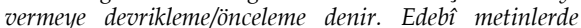
öncelemeler, manayı kuvvetlendirir, duygu yoğunluğu sağlar. Şair ve yazarlar öncelemeyi kendi özgün sanat anlayış ve üslupları gereği tercih ederler. Klasik Türk şiirinde çoğu divanda önceleme örnekleri ile karşılaşılabilir. Çă̆atay edebiyatının önemli şairlerinden olan Bâbur (1483-1530)'un divanı da bu metinlerdendir. Bâbur divanında stilistik bir özellik olarak dikkati çeken öncelemeler: Mèn, sèn, ol, biz ve bu zamirleri; kim, kaysı, kaysı bir, néçe, kanı soru sözcükleri; eger, gehî, hem, né, yene bir bağlamlarl; ayş, dehr, feryâd, gül, hoş ol, hüsn ehli, ışk, kadd, gönül, köz, köz yaşı, kuyaş, nęçe, tarahhum, yaghı ve yaz fash sözcükleri; cinasli, anlamdaş, yakın ve karşıt anlamli, kökteş sözcükler; klasik şiirde sevgili tipine ait unsurları ifade eden kelimeler ve boldı köñlüm, bolgay mu, gâfil olma, ne bilgey-sen eylemleridir.

$$
\text { A N A H T A R K E L İ M E L E R }
$$

Bâbur, önceleme, paralelizm, stilistik inceleme.

\section{A B S T R A C T}

In this article foregrounded and parallel arranged words in poems of Zahir al-din Muhammad Babur (d. 1530) who is a famous Cagatay sultan and poet are studied. This is characteristic of a Babur's style of poems, also it was tradition before İslamic Turkish poetry, so it has gone on Babur's poems.

\section{Giriş}

Herhangi bir cümle öğesine belli bir amaçla ilk sırayı vermeye devrikleme/önceleme denir. Edebî metinlerde öncelemeler, manayı kuvvetlendirir, duygu yoğunluğu sağlar. Şair ve yazarlar öncelemeyi kendi özgün sanat anlayış ve üslupları gereği tercih ederler. Bu nedenle mesela

"Doç. Dr., Marmara Üniversitesi Fen-Edebiyat Fakültesi Türk Dili ve Edebiyatı Bölümü, İstanbul. (uaslan@marmara.edu.tr) 
şiirin hangi sözcükle başlayacağı şiir sanatının inceliklerine göre belirlenir. Öncelemeler, divan şiirinde söz mimarlığı niteliğindedir. Sanatkâr şairler elinde estetik bir kaygı ile bilinçi bir şekilde yapılan düzenlemelerdir bunlar. Öncelenen sözcük, şiirin, beytin ya da misraın eksenindedir. Öncelemeler, kelimelerin dizilişinden doğan ses güzelliği, akıcılık ve duyguda coşkunluk meydana getirir. Öncelemelerde beytin ya da misraın başında yer alan ilk sözcükten sonraki öğeler üzerinde de durulmalıdır, çünkü bunlar mısra ya da beyitte birbirine bağlı biçimde zincirleme olarak manayı pekiştirip duygu ve düşünce boyutlarını genişletiyor olabilirler. (Dilçin 2008: 41-45).

Klasik Türk şiirinde çoğu divanda önceleme örnekleri ile karşılaş1labilir. Çağatay edebiyatının önemli şairlerinden olan Bâbur (14831530)'un divanı da bu metinlerdendir.

XVI. asrın başında Güney Asya'da kendi adıyla anılan bir Türk devleti kurmuş olan Bâbur Şah, Ali Şir Nevayî (1441-1501)'den sonra Çağatay edebiyatının en güçlü edebî şahsiyeti olarak kabul edilir. Tam adı Zahîrü'd-din Muhammed olan Bâbur'un divanı, Vekayi'i, Aruz Risalesi, Mübeyyen'i ve Risale-i Validiyye Tercümesi adlı eserleri bulunmaktadir.

$\mathrm{Bu}$ çalışmanın konusu, Bâbur divanında stilistik bir özellik olarak dikkati çeken öncelemelerdir. Bâbur, üslup özelliği olarak şiirlerinde ses tekrarına ve benzeşmesine dayanan cinas, seci ve irsad; kelime tekrarına dayalı reddü'l-acuz ale's-sadr, iade, akis; mana karşıtlı̆̆ına dayanan tezad; leffüneşr, tensîku's-sıfât, tekrîr gibi edebî sanatları kullanmaktadır. Görüldügü gibi bunlar hem manaya hem de lafza dayanan sanatlardır. Tarsi ile ya da Batı edebiyatındaki paralelizmle ilişkilendirilebilecek olan önceleme, Bâbur'un şiir stilinin bir parçası olarak dikkati çekmektedir. Hopkins, şiir sanatının ve bu sanattaki ustalığın paralelizm esasına dayandığını ifade eder (Akay 1998: 301). Musiki ile de ilişkili olan paralelizm, aynı zamanda musikişinas olan şairin şiirdeki ustalığını ortaya koyması bakımından ele alınması gerekli bir unsurdur.

Önceleme ya da bir sözcüğün misra başında tekrar edilmesi, Türk edebiyatının yalnız klasik döneminde görülen bir düzenleme değildir, zira İslam öncesi eski Türk şiirinde mısra başında (ön ses), ortasında ve sonunda kafiye kullanımı söz konusuydu. Divanu lugâti't-Turk'te adı 
geçen Çuçu'dan daha önce yaşadığı sanılan Aprınçur Tigin'e ait dörtlükler hâlinde yazılmış bir ilahide ön seste $t$ ünsüzü ile kafiye yapılmıştır. Manzumenin ilk dörtlüğü şöyledir:

Tüzün bilge kişiler tirilelim

Teñriniñ bitigin biz işidelim

Tört ilig teñrilerke tapınalım

Tört ulug emgekide kurtulalım ${ }^{1}$ (Arat 1986: 24)

İslam sonrası bu geleneğin devam ettiği tahmin edilebilir. Mesela Âşık Paşa (1272-1332)'nın yahut Yunus Emre (ö. 1321)'nin olduğu ileri sürülen bir gazelde $m$ ünsüzü mısra başında ve ortasında tekrar edilmektedir. Gazelin matla beyti aşağıdadır:

Merdân-1 Hak bu dünyede maksudlara kalmadılar Mülk-i bekâ bulmış iken meyl-i fenâ kılmadılar

(Coşkun 2007: 233) $)^{2}$

XIII. asır şairlerinden Sultan Veled (1226-1312)'in divanında muvaşşah şiirler bulunmaktadır. XV. asır şairlerinden Saruca Kemal'in divançesindeki ilk 29 gazelin her misraının ilk ve son harfi alfabetiktir. Klasik Türk edebiyatı türlerinden olan elif-namelerde eliften ya'ya harfler alfabetik olarak sıralanır. Bu çalışmanın konusu olan Bâbur divanında mısra başı kafiyenin kullanıldığı bir gazel yer almaktadır. Şiir şöyledir:

Şāh Sulțān Üveys bin Maḥmūd

Māh Sulțān Üveys bin Maḥmūd

Kad u aġzıñdın ayru tartar-mèn

Āh Sulțān Üveys bin Maḥmūd

Mèni yād eyle bezm-i 'ş̧ḳıñda

Gāh Sultān Üveys bin Maḥmūd

\footnotetext{
${ }^{1}$ 11'li hece. «Asil, bilge insanlar toplanalım, tanrının kitabını dinleyelim, dört hâkim tanrıya tapınalım, dört büyük azaptan kurtulalım.» Çeviri, alıntı yapılan kaynağın yazarına aittir.

${ }^{2}$ Recez-i müsemmen-i sâlim: müstef'ilün müstef'ilün müstef'ilün müstef'ilün. «Allah adamları bu dünyanın isteklerine tenezzül etmediler. Ölümsüzlük ülkesini bulmuşken yokluğa yönelmediler.»
} 
Hoş-turur hem-rehim eger sèn-sèn

Rāh Sulțān Üveys bin Maḥmūd

Pādşehdür eger-çi Bābur līk

Şāh Sulțān Üveys bin Maḥmūd (Yücel 1995: 179)³

Eski Türk şiirinde mısra başında redif/sözcük kullanımıyla ilgili örneklerle de karşılaşmaktayız. Mesela Turfan yakınlarında yapılan kazıda ele geçen bir şiir mecmuasında şöyle bir dörtlük vardır:

Bilig biliñ ya begim

Bilig saña eş bolur

Bilig bilgen ol erke

Bir kün devlet tuş bolur ${ }^{4}$ (Arat 1986: 259)

Görüldüğü gibi dörtlükte "bilig" sözcüğü mısra başına yerleştirilmiştir. Türk şiirinin karakteristik özelliklerinden olduğunu düşündüğümüz bu düzenlemenin İslam sonrasında da sürdürüldüğü tahmin edilebilir. Böylece öncelemelerin, klâsik Türk şiirinin milli yönünü gösteren unsurlardan biri olduğunu söyleyebiliriz.

Bâbur divanında stilistik bir özellik olarak dikkati çeken öncelemeler: Mèn, sèn, ol, biz ve bu zamirleri; kim, kaysı, kaysı bir, nėçe, kanı soru sözcükleri; eger, gehî, hem, nè, yene bir bağlamları; ayş, dehr, feryâd, gül, hoş ol, hüsn ehli, ışk, kadd, gönül, köz, köz yaşı, kuyaş, nèçe, tarahhum, yaglıg ve yaz faslı sözcükleri; cinaslı, anlamdaş, yakın ve karşıt anlamlı, kökteş sözcükler; klasik şiirde sevgili tipine ait unsurları ifade eden kelimeler ve boldı köñlüm, bolgay mu, gâfil olma, ne bilgey-sen eylemleridir. Son kısımda divanda yer alan 111. şiirle ilgili bir tamir teklifi de yapılmıştır.

Çalışmada bazı kısaltma ve işaretler kullanılmıştır. Bunlar: Ar. Arapça, BD. Bâbur divanı, F. Farsça, T. Türkçe, [ ] metne eklenen bölüm,

\footnotetext{
${ }^{3}$ Hafîf-i müseddes-i mahbûn: fâ'ilâtün mefâ'ilün fa'lün. «Sultan Üveys b. Mahmud şahtır, o aydır. Boyu ve ağzından ayrı ah çekerim. Aşk meclisinde ara ara beni an. Ey Sultan Üveys b. Mahmud! Eğer yoldaşım sensen yol hoştur. Bâbur her ne kadar padişahsa da Sultan Üveys b. Mahmud şahtır.»

${ }^{4} 7$ 'li hece. «Bilgi bilin, ey beyim! Bilgi sana eş olur, bilgi bilen insana bir gün devlet yar olur.» Çeviri kaynağın yazarına aittir.
} 
\{ \} metinden çıkarılan bölüm. Beyit sonunda verilen rakamlar sırasıyla sayfa numarası/şiir numarası-beyit nuramasını ifade eder. Çalışmamız Yücel'in (1995) yayınına dayanmaktadır.

\section{Bâbur Divanında Öncelemelerve Öncelemelerde Paralelizm}

\section{Sözcük Öncelemeleri}

\subsection{Zamirler}

Bâbur divanında "mèn, sèn, ol, biz ve bu" zamirleri öncelenmektedir. Bunlar manzumenin aynı beytinde olabildiği gibi çoğunlukla art arda gelen farklı beyitlerinde de yapılabilmektedir. Farklı beyitlerdeki öncelemelerde düzenli olarak ilk ya da ikinci mısrada önceleme yapılmakta, kimi zaman da bu öncelemeler düzensiz biçimde, ilk beytin birinci, ardından gelen beytin ise ikinci misrainda olabilmektedir.

Mèn:

Divandaki 108. gazelin 8 . beytinde mèn zamiri öncelenmiştir. İlk mısrada "mèn" özne, ikinci mısrada nesne konumundadır.

Mèn èliktin barıp-èrdim tutup èlgimni birev

Mèni oyġattı köz açtım-èse ol meh-veş èdi $(182 / 108-8)^{5}$

Farklı beyitte:

49. gazelin art arda gelen aşağıdaki beyitlerinin ilk mısraında önceleme yapılmış, Mèni ḩvār ètti... Mèni öltürdi biçiminde kısmi bir paralellik/tarsi de sağlanmıştır.

Mèni ḩvār ètti vü ḳıldı müddecini perveriş

Dehr-i dūn-perverniñ özge müdde’āsı ḳaldı mu

\footnotetext{
${ }^{5}$ Remel-i müsemmen-i mahbûn-1 mahzûf-1 aslem-i darb: Fe'ilâtün fe'ilâtün fe'ilâtün fe'ilün. «Ben elden çıkmıştım, birisi elimi tutup beni uyandırdı, gözümü açtığımda ise o ay gibi (güzel) vard1.» Diğer örnekler: 139/36-1, 143/43-6, 161/72-3, 167/82-3.
} 
Mèni öltürdi cefā vü cevr birle ol ḳuyaş

Émdi tirgüzmek üçün mihr ü vefāsı ḳaldı mu $(147 / 49-2,3)^{6}$

Sèn:

Sèn zamiri 63. gazelin 5. beytinde dolaylı tümleç öğesi olarak öncelenmiştir.

Sèndin ayrıldım-ėse boldı nașībim hār-1 gam

Sẻndin èy gül ėmdi Bābur bir zamān ayrılmag̉ay $(156 / 63-5)^{7}$

Farklı beyitte:

67. gazelin 5. ve 6 . beyitlerinin ilk misrainda sẻn zamiri yine dolaylı tümleçtir.

Saña bir yol yėter fikridedür-mèn

Unutma bir yolı efgārlarnı

Saña köñlümni aldurdum cihānda

Körüp-mėn gerçi köp dildārlarnı $(158 / 67-5,6)^{8}$

Ol:

Ol, şu beyitlerde üçüncü tekil şahıs zamiridir ve ki bağlamı ile birlikte öncelenmiştir.

Ol ki yıllar aylar ötkergey gam u mātem bile

Şād u hưrrem bolmaġay nev-rūz ile bayrām bile

Ol ki devrānnıñ ayağıdın dem-ā-dem ḳan yutar

Neş'e tapmas ger içer her devr-i cām-1 Cem bile (179/104-1, 2) ${ }^{9}$

\footnotetext{
${ }^{6}$ Remel-i müsemmen-i mahzûf: Fấilâtün fấilâtün fấilâtün fâ'ilün. «Beni hakir etti, inatçıyı yetiştirdi, ilerletti. Soysuz yetiştiren dünyanın başka iddiası kaldı mı? O güneşe benzer sevgili haksızlık ve eziyetle beni öldürdü, şimdi diriltmek için sevgisi ve vefası kaldı mı?» Diğer örnekler: 140/39-1, 2; 188/120-2, 3.

${ }^{7}$ Remel-i müsemmen-i mahzûf: Fấ'ilâtün fấ'ilâtün fấ'ilâtün fâ'ilün. «Senden ayrılınca nasibim gam dikeni oldu. Ey gül! Bâbur şimdi senden hiç ayrılmayacak.» Diğer örnek: 125/13-3.

${ }^{8}$ Hezec-i müseddes-i mahzûf: Mefâ'îlün mefấ̂̂lün fe'ûlün. "Sana bir yol yeter düşüncesindeyim, bir yandan da yaralı âşıklarını unutma. Her ne kadar dünyada pekçok güzel gördümse de gönlümü ben sana kaptırdım.»
} 
Biz:

Bâbur divanında "biz" zamirinin öncelendiği yalnız bir örnek tespit edildi. Bu örnekte biz, ilk misrada + dIn, ikinci misra da ise $+n I$ hâl eki alarak dolaylı tümleç konumundadır.

Bizdin ayru dā’im èl birle içer-sèn bādeni

Bizni hem gāhì șaġın şürb-i müdāmıñ barıda $(125 / 14-4)^{10}$

$\mathrm{Bu}:$

Yine tek örnekte karşılaştığımız "bu", 53. gazeldeki 4. ve 5. beyitlerin ikinci mısraında işaret sıfatı olarak öncelenmiştir.

Yarım kèçeler kelür-èrdi burun

Bu tün kèlmedi āh yārım ḳanı

Dėmeñ terk-i 'ş̧ḳını ḳıl ihtiyār

Bu işde mèniñ iḩtiyārım ḳanı $(149 / 53-4,5)^{11}$

\subsection{Soru sözcükleri}

Bâbur divanında kim, ḳaysı, ḳaysı bir, nėçe, ḳanı soru sözcükleri öncelenmektedir.

Kanı "Hani":

57. gazelde gördüğümüz tek örnekte "ḳanı" soru sözcüğü öncelenmiştir. Beyitte Kanı Şīīn bile Leylī ki ... Kanı Ferhād u Mecnūn kim... şeklinde paralelizm sağlanmıştır.

\footnotetext{
${ }^{9}$ Remel-i müsemmen-i mahzûf: Fâ'ilâtün fâ'ilâtün fâ'ilâtün fâ'ilün. «Gamla matemle aylar yıllar geçiren o, nevruzla bayramla mutlu olmaz. Devranın kadehinden her an kan yutan $\mathrm{o}, \mathrm{Cem}$ 'in dönen her kadehinden içse de neşe bulmaz.» Diğer örnekler: 148/52-1, 2; 171/90-1, 4.

${ }^{10}$ Remel-i müsemmen-i mahzûf: Fâ'ilâtün fâ'ilâtün fâ'ilâtün fâ'ilün. «Şarabı bizden ayrı daima başkalarıyla birlikte içersin, içecek şarabın varken bir zaman bizi de düşün.» Müdâm 'şarap' demektir, bk. Kurnaz 1993: 76.

${ }^{11}$ Mütekârib-i müsemmen-i mahzûf: Fe'ûlün fe'ûlün fe'ûlün fe'al. «Sevgilim önce geceleri/gece yarıları gelirdi, bu gece gelmedi, ah sevgilim hani? Aşkı terk etmeyi seç, demeyin. Bu işte benim iradem hani?»
} 


\begin{tabular}{|l|l|l|l|l|l|}
\hline Kanı & Şīīn bile Leylī & ki & sèndin & nāz & örgense \\
\hline Kanı & Ferhād u Mecnūn & kim & alarġa & 'ş̧ & örgetsem \\
\hline
\end{tabular}

Kanı Şīiñ bile Leyli ki sẻndin nāz örgense

Kanı Ferhād u Mecnūn kim alarg̉a 'sş̧̣ örgetsem (152/57-3) ${ }^{12}$

Kays1 "Hangi":

76. gazelin 3. beytindeki "ḳaysı" öncelemesi Bâbur'un şiir stilini gösteren güzel bir paralelizm örneğidir. Her iki misrada cümle öğeleri aynı sıra ile yerleştirilmiştir. Bu durum aşağıdaki tabloda daha iyi görülebilir:

\begin{tabular}{|l|l|l|l|l|}
\hline Kaysı & hasret & birle & ārmānın & vefāsız vaṣlnıñ \\
\hline Kaysı & miḥnet & birle & rencin & furḳat-ı hūn-ḩ̌ārnıñ \\
\hline
\end{tabular}

Kaysı hạsret birle ārmānın vefāsız vaṣlnıñ

Kaysı miḥnet birle rencin furḳat-1 hūn-ḩvārnıñ $(163 / 76-3)^{13}$

Kaysı bir "Hangi bir":

76. gazelin 1 ve 2. beyitlerinde "Kaysı bir" sözcüğü her mısrada öncelenmiştir. Beyitlerdeki paralelizm yine dikkati çekicidir.

\begin{tabular}{|l|l|l|l|l|}
\hline Kaysı bir & āzārın & aytay & cānıma & ag̉yārnıñ \\
\hline Kaysı bir & aġrıtkanın & köñlümni & dėy & dildārnıñ \\
\hline Kaysı bir & bī-rehlığını & & & țāli'-i güm-rāhnıñ \\
\hline Kaysı bir & keç-revlıġını & & & çarh̆-ı keç-reftārnıñ \\
\hline
\end{tabular}

Kaysı bir āzārın aytay cānıma ag̉yārnı̃̃

Kaysı bir ag̉rıtḳanın köñlümni dèy dildārnıñ

Kaysı bir bī-rehlıġını țāli'-i güm-rāhnıñ

Kaysı bir keç-revlı̀̇ını çarh-ı keç-reftārnı̃̃ (163/76-1, 2)

${ }^{12}$ Hezec-i müsemmen-i sâlim: Mefâ'îlün mefâ'îlün mefâ'îlün mefâ'îlün. «Hani Şirin ile Leyla? Senden naz öğrensinler. Hani Ferhad ile Mecnun? Onlara aşk öğreteyim.»

${ }^{13}$ Remel-i müsemmen-i mahzûf: Fâ'ilâtün fâ'ilâtün fâ'ilâtün fâ'ilün. «Vefasız kavuşmanın hangi özlemiyle arzusunu, kan dökücü ayrılığın hangi sıkıntısıyla eziyetini (diyeyim).» 
Kim:

16. gazelin matla beytinde "Kim" soru zamiri öncelenmiştir. Beytin mısraları arasında cümle öğelerinin sıralanışı açısından bir paralellik vardir.

\begin{tabular}{|l|l|l|l|l|l|}
\hline Kim & körer & hurrşīini & ol & māh-sīmā & bolmasa \\
\hline Kim & sorar & şekkerni & ol & la'l-i şeker-ḩā & bolmasa \\
\hline
\end{tabular}

Kim körer huurşīini ol māh-sīmā bolmasa

Kim sorar şekkerni ol la'l-i şeker-ḩā bolmasa (126/16-1 $)^{15}$

Nèçe "Nasil":

"Nėçe" soru sözcüğü 97. gazelin 4. beytinde öncelenmiştir. Beyitteki paralelizm ise şöyle gösterilebilir:

\begin{tabular}{|l|l|l|l|l|l|l|}
\hline Nèçe & teḡāfül & ètip & maña & baḳmayın & yörür & ol \\
\hline Necçe & tażarru' & ètip & mèn & aña & baḳı & turayın \\
\hline
\end{tabular}

Nèçe tegāfül ètip maña baḳmayın yörür ol

Nėçe tażarru' ètip mèn aña baḳıp turayın (176/97-4) ${ }^{16}$

\subsection{Bağlamlar}

Bâbur divanında eger, gehî, hem, ne ve yene bir bağlamlarıyla önceleme yapilmaktadir.

14 Remel-i müsemmen-i mahzûf: Fâ'ilâtün fâ'ilâtün fâ'ilâtün fâ'ilün. "Canıma rakiplerin azarının hangi birini diyeyim, gönlüme sevgilinin verdiği ağrıların hangi birini söyleyeyim? Yolunu kaybetmiş talihimin hangi şaşkınlığını, yamuk giden çarkın hangi eğriliğini anlatayım?»

${ }^{15}$ Remel-i müsemmen-i mahzûf: Fâ'ilâtün fâ'ilâtün fâ'ilâtün fâ'ilün. «O ay yüzlü olmasa güneşi kim görür? O şeker çiğneyen lal dudak olmasa şekeri kim emer?» Diğer örnekler: 125/14-1, 132/24-1. Şeker çiğnemek: hoşa gidecek şekilde imalı söz söylemek, yalandan vaatte bulunmak anlamindadır.

${ }^{16}$ Müctess-i müsemmen-i mahbûn-1 mahzûf: Mefâ'ilün fe'ilâtün mefâ'ilün fe'ilün. «O nasıl aymazlık edip bana bakmadan yürür? Ben nasıl yalvararak ona bakıp durayım?» Diğer örnek, farklı beyitte: 188/120-4, 6 . 
Eger:

50. gazelin matla ve hüsn-i matla beyitleri olan 1 . ve 2. beyitlerinde "eger" bağlamı öncelenmiştir. Matla beytinde 2. mısrada, hüsn-i matla beytinde ise 1. misrada öncelenerek iki beyit arasında anlam bütünlüğü sağlanmaktadır.

Meniñ köñlüm ki gülniñ ġonçası dèk teh-be-teh ḳandur

Eger yüz miñ bahār olsa açılmaġı nẻ imkāndur ${ }^{17}$

Eger ol ḳaşı yāsız bāg̉ geştin ārzū ḳılsam

Közümge oḳ-durur serv ü köñülge ġonça peykāndur (147/50-1, $2)^{18}$

Gehì:

57. gazelin 2. beytinde "Gehî" bağlamı öncelenmiştir. Mısralar arasinda yine paralellik söz konusudur.

\begin{tabular}{|l|l|l|l|l|l|l|l|}
\hline Gehì & gül & dèk & yüzini & ol & şeker sözlükniñ & & islesem \\
\hline Gehì & şekker & kibi & & ol & yüzi gülniñ & la'lidin & tatsam \\
\hline
\end{tabular}

Gehỉ gül dèk yüzini ol şeker sözlükniñ islesem

Gehì şekker kibi ol yüzi gülniñ la'lidin tatsam $(152 / 57-2)^{19}$

Hem:

60. gazelin 3. beytinde "Hem" öncelenmiştir. Beyitte misralar arasinda paralelizm oluşturulmuştur.

\begin{tabular}{|l|l|l|l|l|}
\hline Hem & lāle & yüzüñ & ḳaşıda & bì-reng \\
\hline Hem & serv & ḳadıñ & barıda & bì-pāy \\
\hline
\end{tabular}

${ }^{17}$ Hezec-i müsemmen-i sâlim: Mefâ'îlün mefâ'îlün mefâ'îlün mefâ'îlün. «Gül goncası gibi kat kat kan olan benim gönlümün açılması yüz bin kez bahar olsa yine de mümkün değildir.»

18 «Eğer o yay kaşlı olmadan bağ gezintisini arzulasam servi gözüme ok, gonca gönlüme temren olur.»

${ }^{19}$ Hezec-i müsemmen-i sâlim: Mefâ'îlün mefâ'îlün mefâ'îlün mefâ'îlün. «Kimi zaman o şeker sözlü (sevgilinin) gül gibi yüzünü koklasam, kimi zaman o gül yüzlü (sevgilinin) şeker gibi lâl (dudağından) tatsam.» Diğer örnek: 160/71-2. 
Hem lāle yüzüñ ḳaşıda bī-reng

Hem serv ḳadıñ barıda bī-pāy $(154 / 60-3)^{20}$

Nè:

Aşağıda verilen örnek beyitte " $\mathrm{Ne}^{\prime}$ bağlamı ile önceleme yapılmış, mısralardaki sözcükler paralelizm esasına göre sıralanmıştır.

\begin{tabular}{|l|l|l|l|l|l|l|l|}
\hline Nè & cefā & țavrıda & bar & dünyìde & ol & bì-mihr & dèk \\
\hline Nè & vefā & bābıda & bar & 'ālemde & mèn & şeydā & kibi \\
\hline
\end{tabular}

Nè cefā țavrıda bar dünyīde ol bì-mihr dèk

Nè vefā bābıda bar 'ālemde mèn şeydā kibi (143/43-6) ${ }^{21}$

Yene bir "Yine bir":

Bâbur divanındaki 121. gazelin matla beytinde "yene bir" bağlamı öncelenmiştir. Beyitte yine bir paralelizm söz konusudur.

\begin{tabular}{|l|l|l|l|l|l|}
\hline Yene & bir & köz ġamıdın & hasta & körer-mèn & özni \\
\hline Yene & bir & zülfg்a & vābeste & körer-mèn & özni \\
\hline
\end{tabular}

Yene bir köz gamıdın hasta körer-mėn özni

Yene bir zülfğa vābeste körer-mėn özni (189/121-1)

\subsection{Diğer sözcükler}

Bâbur divanında ayş, dehr, feryâd, gül, hoş ol, hüsn ehli, ışk, kad, köñül, köz, köz yaşı, kuyaş, nèçe, tarahhum, yaglıg ve yaz faslı sözcükleri öncelenmektedir.

${ }^{20}$ Hezec-i müseddes-i ahreb-i makbûz-1 mahzûf: Mef'ûlü mefâ'ilün fe'ûlün. «Hem lale, yüzün yanında renksiz; hem servi, boyun varken şaşkın.»

${ }^{21}$ Remel-i müsemmen-i mahzûf: Fâ'ilâtün fâ'ilâtün fâ'ilâtün fâ'ilün. «Eziyet etmede dünyada ne o zalim gibisi var, sevgi ve bağlılıkta âlemde ne ben gibi çılgın var.» Diğer örnekler: 125/14-1, 143/43-1, 161/73-1, farklı beyitte: 131/23-6, 7; 140/37-3, $4 ; 172 / 91-1,2 ; 181 / 107-3,5 ; 186 / 116-1,2$.

${ }^{22}$ Remel-i müsemmen-i mahbûn-1 maktû': Fe'ilâtün fe'ilâtün fe'ilâtün fa'lün. "Yine bir gözün gamından ben kendimi hasta görüyorum, yine bir zülüfe kendimi bağlanmış görüyorum.» Diğer örnek: 127/17-1, 2. 
'Ayş "Yaşama, eğlenme":

79. gazelin art arda gelen 3. ve 4. beyitlerinde "Ayş" sözcügü öncelenmiş olup devrikleme 3 . beyitte 1 . misrada iken 4 . beyitte 2 . misradadir.

'Ayş u tarab gül-büniga su bèrip

Gussa nihālini ḳurutmaḳ kèrek

Her nèmege gam yème gam köp-turur

'Ayş bile özni avutmak kèrek $(165 / 79-3,4)^{23}$

Dehr "Dünya":

Divandaki 80. gazelin 2. beytinde "dehr" sözcüğü öncelenmiştir, beyitte yine bir paralelizm söz konusudur.

\begin{tabular}{|l|l|l|l|l|}
\hline Dehr-i dūndın & āzār tègmesün & nāzük & cismiñe & \\
\hline Dehr ehlidin & & mübārek & köñlüñe & gam bolmasun \\
\hline
\end{tabular}

Dehr-i dūn[dın] tègmesün āzār nāzük cismiñe

Dehr ehlidin mübārek köñlüñe ġam bolmasun $(165 / 80-2)^{24}$

Feryād:

Aşağıdaki beyitlerde "feryâd" sözcüğü önceleniyor. Önceleme, ilk beytin 2 . misraında iken ikinci beytin 1. misraındadır. Böylece beyitler arasında manaca bir bağlantı sağlanmış oluyor.

Kıılsam saña her nėçe taz̧allum

Feryād u fiḡān ki dād tapman

Feryād ki dèrge 'işḳ rāzın

Bir kişini i'timād tapman (188/119-3, 4)

${ }^{23}$ Serî'-i müseddes-i matvî-i mekşûf: Müfte'ilün müfte'ilün fâ'ilün. «Eğlence ve sevincin gül ağacına su verip keder fidanını kurutmak gerek. Her şeye üzülme, üzüntü çoktur, eğlenerek kendini avutmalısın.»

${ }^{24}$ Remel-i müsemmen-i mahzûf: Fâ'ilâtün fâ'ilâtün fâ'ilâtün fâ'ilün. «Aşağılık dünyadan nazik bedenine sıkıntı değmesin, dünya halkından mübarek gönlüne üzüntü gelmesin.»

${ }^{25}$ Hezec-i müseddes-i ahreb-i makbûz-1 mahzûf: Mef'ûlü mefâ'ilün fe'ûlün. «Her ne kadar çok yanıp yakılsam da senden karşılık bulamam, vah eyvah. Aşk sırrını söylemeye güvenilir bir kişi bulamam, eyvah.» 
Gül:

Divandaki 44. gazelin matla ve hüsn-i matla beyitlerinde "gül" sözcüğü öncelenmiştir.

Gül cemālın yapḳan ol gülniñ iki reyḥānıdur

Ġonça sırrın açḳan ol ikki leb-i ḩandānıdur

Ol müselsel ikki zülfi gül yüziniñ üstide

Gül üze ag̉nar meger ol ikkiniñ devrānıdur (143/44-1, 2) $)^{26}$

Hoş ol:

Bâbur divanında yer alan 5 beyitlik 117. gazelin 1., 3. ve 5 . beyitlerinde "hoş ol" sözcüğü öncelenmiştir. Ayrıca matla beytinin ilk misraı son beyitte de tekrar edilerek redd-i matla yapılmıştır. Beyitlerde yine bir paralelizm söz konusudur.

\begin{tabular}{|l|l|l|l|l|l|l|}
\hline Hoş ol & & kim & yārdın & ḳat' eyleben & terk-i diyār & ètse \\
\hline Hoş ol & āzāde & kim & $\begin{array}{l}\text { èlniñ } \\
\text { arasıdın }\end{array}$ & & kenār & ètse \\
\hline Hoş ol & & kim & yārdın & ḳat' eyleben & terk-i diyār & ètse \\
\hline
\end{tabular}

Hoos ol kim yārdın ḳat' eyleben terk-i diyār ètse

Cihān kèzmek bile bì-ḳaydlıg̉nı ihtiyār ètse

Cefādur cāng̉a bolmag̉lı̀ muḳayyed 'ālem ehlıg̉a

Hơş ol āzāde kim èlniñ arasıdın kenār ètse

Diyār u yārdın Bābur cefā vü cevr köp kördi

Hoş ol kim yārdın ḳat' eyleben terk-i diyār ètse (186/117-1, 3, 5) ${ }^{27}$

${ }^{26}$ Remel-i müsemmen-i mahzûf: Fâ'ilâtün fâ'ilâtün fâ'ilâtün fâ'ilün. «O gülün gül cemalini örten iki reyhanıdır. Gonca (ağzın) sırrını açan gülen o iki dudağıdır. Gül yüzünün üstündeki o iki zincir zülüf gül üstüne düşer; meğer bu onların devranıymış.» Üstide: devride BD.

${ }^{27}$ Hezec-i müsemmen-i sâlim: Mefâ'̂̂lün mefâ'̂̂lün mefâ'îlün mefâ'̂̂lün. «Dosttan ayrılıp ülkeyi terk etmek, dünyayı gezip özgür olmayı seçmek hoştur. Dünya halkına bağlı olmak cana eziyettir. Halkın arasından köşeye çekilen özgür kişi, güzel kişidir. Bâbur ülkeden ve yardan çok eziyet ve sıkıntı gördü, dosttan ayrılıp ülkeyi terk etse hoştur.» 
Hüsn ehli "Güzeller":

Art arda gelen aşağıdaki beyitlerde "hüsn ehli" sözcüğü misra başında yer almaktadır. Sözcük, ilk beytin 1. misraında, ikinci beytin ise son misrainda öncelenmektedir.

Ḥüsn ehli èy köñül 'ālem ara 'ış̧̣ ehliniñ

Köñlini sahllar ėmiş her kimge kim dildār èmiş

Ol vefāsız yārdın çèkmek nẻ ya'nī munça gàm

Hüsn ehli çün-ki Bābur dünyide bisyār èmiş $(153 / 58-5,6)^{28}$

'Işḳ:

Bâbur divanında 146. gazelin 7. beytinde "1şk" sözcügü öncelenmiştir.

'Iş̧ ile dīvānelıg̉da bolmışam șāḥib-kemāl

'Işk ehli èmdi Bāburnı dègey-siz żū-fünūn (145/146-7) ${ }^{29}$

Kad "Boy":

"Kad" sözcüğü 45. gazelin 4. ve 5. beyitlerinin 2. misralarında öncelenmektedir. Mısralardaki sözcüklerin sıralanmasında bir paralellik de vardir.

\begin{tabular}{|l|l|l|l|}
\hline Kaddıñ & ki & hüsn bāg̀ida & nāzük nihāldur \\
\hline Kaddım & meger ki & derd yanıdaġı & dāldur \\
\hline
\end{tabular}

'Uşşāk āhı yẻlidin āsīb tègmesün

Kaddıñ ki hü̈sn bāgìda nāzük nihāldur

Köñlümge derd kèlgeli ham boldı ḳāmetim

Kaddım meger ki derd yanıdag̀ı dāldur $(144 / 45-4,5)^{30}$

${ }^{28}$ Remel-i müsemmen-i mahzûf: Fâ'ilâtün fâ'ilâtün fâ'ilâtün fâ'ilün. «Ey gönül! Güzeller kime sevgili iseler dünyada âşıklarının gönlünü saklarlarmış. Ey Bâbur! Dünyada güzeller çok olduğuna göre sevgisi çabuk geçen o yardan bunca gam çekmek niye?»

${ }^{29}$ Remel-i müsemmen-i mahzûf: Fâ'ilâtün fâ'ilâtün fâ'ilâtün fâ'ilün. "Aşk ile divanelikte olgunlaşmışım. Ey aşk ehli! Şimdi siz Bâbur'a maharet sahibi deyin.»

${ }^{30}$ Muzâri'-i müsemmen-i ahreb-i mekfûf-ı mahsûf: Mef'ûlü fâ'ilâtü mefâ'îlü fâ'ilün. «Güzellik bağında nazik bir fidan olan boyuna âşıkların ah yelinden zarar gelmesin. Gönlüme dert geldiğinden beri boyum büküldü. Meğer boyum derddeki dalmış.» 


\section{Köñül "Gönül":}

38. gazelin 3. beytinde "könüll" sözcügü öncelenmiştir.

Könülde ḥasreti ol aynıñ aġzınıñ çü bì-ḩaddur

Köñül gūyā ki mundın dūr tutuptur gonça endāmın (140/38-3)

Farklı beyitte:

Tenımġa nėçe-kim nez̧āāe ḳılsañ dāg körgey-sèn

Köñülde her nėçe-kim isteseñ āzār tapḳay-sèn

Bu meh-veşlarga köñlüñ bèrmegil kim asray almaslar

Köñülni asraġıl bolġay ki bir dildār tapḳay-sẻn $(177 / 99-4,5)^{32}$

Köz, köz yaşı "Göz, gözyaşı":

17. gazelin 5. beytinde "köz" sözcüğü önceleniyor.

Közümdin yaşunup èy baḥr-1 elțāf

Közümniñ yaşını deryā ḳılıp-sèn (127/17-5)

Aşağıdaki örneklerde ise "köz yaşı" sözcüğü mısra başında yer al1yor.

Tıya alman yı̇̇ını körgeç ol yaşnı veli ol hem

Közüm yaşını körgeç asray almas özni külgüdin

Közüm yaşı ki yẻmrüldi şekīb ü șabr öyi andın

Ziyānlar saña èy Bābur bu yañlı̀ bilmedim sudın (166/81-4, 5)

${ }^{31}$ Hezec-i müsemmen-i sâlim: Mefâ'îlün mefâ'îlün mefâ'îlün mefâ'îlün. «O ayın ağzının özlemi könülde sınırsızdır. Sanki gönül goncayı bundan uzak tutmaktadır.»

32 «Tenime ne zaman baksan yara görürsün. Her ne zaman istesen gönülde incinme bulursun. Bu ay gibi (sevgililere) gönül verme, saklamazlar. Gönlünü sakla, ola ki bir sevgili bulursun.»

${ }^{33}$ Hezec-i müseddes-i mahzûf: Mefâ'̂̂lün mefâ'îlün fe'ûlün. «Ey lütuflar denizi! Gözümün yaşını gözümden gizleyip deniz ettin.»

${ }^{34}$ Hezec-i müsemmen-i sâlim: Mefâ'îlün mefâ'îlün mefâ'îlün mefâ'îlün. «O ufak tefek (sevgilimi) görünce ağlamayı yasaklamam, ama o gözümün yaşını görünce kendisine gülmeyi yasaklamaz. Sabır ve tahammül evini yıkan gözyaşım gibi bir su bilmiyorum, ey Bâbur! Yazıklar sana.» 
Kuyaş "Güneş":

85. gazelin matla ve hüsn-i matla beyitlerinde "kuyaş" sözcügü öncelenmiştir. Önceleme, 1 . beytin ilk misraında, 2. beytin ise 2. misraindadir.

Kuyaşım her sarığa 'azm ḳılsa zerere'ī ḳalman

Nè üçün kim eger ayrılsam andın kün köre alman

Anıñ dèk bolmışam ḥayrān ḳuyaş yañlı̀ yüzüñe kim

Kuyaş dèk nīzeler tègse közümge köz ala alman $(168 / 85-1,2)^{35}$

Nèçe "Çok":

64. gazelin 3. beytinde "nęçe" sözcüğü öncelenmiştir.

Nèçe körsetsem vefā vü mihr èter cevr ü cefā

Nėçe kim mèn zār-mèn méndin ol ay bī-zārdur (156/64-3)

\section{Taraḥḥum "Acıma":}

95. gazelin 2 ve 4 . beyitlerinde "tarahhum" sözcüğü öncelenmektedir.

Taraḥḥum yüzidin yüzüñi körmekke buyurgaay-sẻn

Hoş ol kim ‘ārıżıñnı körge-mèn sözüñ ėşitkey-mèn

Taraḥhum ḳılmasañ yā baḳmay istignnā bile ötseñ

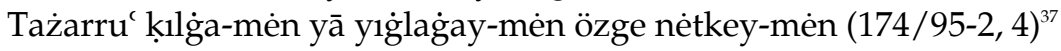

${ }^{35}$ Hezec-i müsemmen-i sâlim: Mefâ'îlün mefâ'îlün mefâ'îlün mefâ'îlün. «Güneşim her ne yöne gitse zerrem kalmaz. Bir sebeple ondan ayrılsam gün yüzü göremem. Onun gibi güneşe benzer yüzüne de hayran olmuşum, güneş (ışılları) gibi mizraklar gözüme deyse gözümü ayıramam.»

${ }^{36}$ Remel-i müsemmen-i mahzûf: Fâ'ilâtün fâ'ilâtün fâ'ilâtün fâ'ilün. «Sevgi ve vefa gösterdiğim onca zamandır bana eziyet ve sıkıntı eder. Ağladığım onca zamandır o ay (gibi sevgili) benden sıkılır.» Diğer örnek: 189/122-3, farklı beyitte: 176/99-1, 2, 3; 184/113-1, 2; 186/116-2, 3. 113. Gazelin matla beytinin 2. misraı BD'de şöyledir:

Hāṭırımnı nèçe zülfüñ dèk perişāann ḳılġa-sèn

Bâbur'un şiir stili göz önünde bulundurularak mısra tamir edilebilir ve beyit şu şekilde olabilir:

Nėçe la'liñ dèk mėniñ bag̉rım tola ḳan ḳılga-sèn

Nèçe zülfüñ dèk mèniñ köñlüm perişsān ḳ1lga-sèn (184/113-1) 
Yağlig "Mendil":

70. gazelin matla beytinde "yaglıg" sözcügü öncelenmiş, 4 . beyitte ise aynı sözcük öncelenerek tekrar edilmiştir.

Yag̉lı่̀ıñ kim cān bile mèn hastadur mèn zār aña

Hasta cānlar riştesidindür meger bir tār aña

Yağlığıñ tā kim yüz ü közüñe tẻgmiş bar-durur

Yüz mèniñ dèk zār u yüz miñ mèn kibi bīmār aña $(160 / 70-1,4)^{38}$

Yaz faṣlı "Yaz mevsimi":

109. gazelde matla ve hüsn-i matla beyitlerinde "yaz faslı" sözcüğü mısra başındadır. Her iki beyitte de önceleme ilk mısrada yapılmıştır.

Yāz faṣlı yār vaṣlı dōstlarnıñ șoḥbeti

Şi'r bahṣı1 'ş̧⿻ derdi bādeniñ keyfiyyeti

Yāz faṣlıda çaġır içmekniñ özge hāāı bar

Kimge bu neş'e müyesser bolsa bardur devleti (182/109-1, 2) ${ }^{39}$

\subsection{Cinaslı sözcükler}

68. gazelin matla beytinde yā [< T. "yay"] ile yā [<F. "yahut"] cinaslı bir şekilde kullanılarak öncelenmiştir. Ayrıca mısralar arasında paralellik de vardır.

${ }^{37}$ Hezec-i müsemmen-i sâlim: Mefâ'îlün mefâ'îlün mefâ'îlün mefâ'îlün. «Acıma yüzünden yüzünü görmeyi buyurursun. Hoş olan şu ki yanağını görüyor, sözünü işitiyorum. Acımasan veya gururla bakmadan geçsen yalvarırım veya ağlarım, başka ne yapayım?»

${ }^{38}$ Remel-i müsemmen-i mahzûf: Fâ'ilâtün fâ'ilâtün fâ'ilâtün fâ'ilün. «Ben âcizin candan hasta olduğu mendilinin bir ipi, meğer hasta canların rişte illetiymiş. Yüzüne gözüne deydiğinden beri mendilinin benim gibi yüzlerce âcizi, yüz binlerce hastası vardır.» Rişte illeti, çoğunlukla ayağın topuk kısmında görülür. Kırılsa veya kesilse kişi helak olur. Bu hastalık genellikle Lâr şehrinde ortaya çıkar, Tiflis ve Kudüs'te görülmüştür; bk. Öztürk-Örs 2000: 631.

${ }^{39}$ Remel-i müsemmen-i mahzûf: Fâ'ilâtün fâ'ilâtün fâ'ilâtün fâ'ilün. «Yaz mevsimi, sevgiliye kavuşma, dostlarla sohbet, şiir konusu, aşk derdi, şarabın verdiği keyif. Yaz mevsiminde şarap içmenin başka bir hâli var. Bu neşe kime nasip olursa onun talihi vardır.» 


\begin{tabular}{|l|l|l|l|l|l|}
\hline Yā & ḳaşıñ & yañlı̀ & ègilgen & cism-i zārımnı mu & dèy \\
\hline Yā & saçıñ & dèk & tïre bolg̀an & rūzgārımnı mu & dèy \\
\hline
\end{tabular}

Yā ḳaşıñ yañlı̀ ègilgen cism-i zārımnı mu dẻy

Yā saçıñ dèk tïre bolg̀an rūzgārımnı mu dèy $(159 / 68-1)^{40}$

23. gazelin 3. ve 4 . beyitlerinde kaş $[<$ T. "kaş"] ile kaş $[<\mathrm{T}$. "karş1, ön"] kelimeleri öncelenmiştir. Bu kelimeler arasında cinas vardır.

Kaşıda çīn közide kīn ü engübīn lebide

Sözide zehr velīkin tilide dermāndur

Kaşııña köp bara alman nètey aralıḳda

Yaşım tişiñ düridin ayru baḥr-1 'ummāndur (131/23-3, 4)

\subsection{Anlamdaş sözcükler}

69. gazelin 2. beytindeki "yan" ve "sarı" sözcükleri yön bildirirler, dolayısıyla anlamdaştırlar. Beyitte her iki kelime de misra başında yer almış, ayrıca paralelizm oluşturulmuştur.

\begin{tabular}{|l|l|l|l|l|l|l|}
\hline Her & yanga & ki & 'azm ètsem & yanımda & barur & miḥnet \\
\hline Her & sarı & ki & yüzlensem & utrumġa & kèlür & ḳag்u \\
\hline
\end{tabular}

Her yanga ki 'azm ètsem yanımda barur miḥnet

Her sarı ki yüzlensem utrumġa kèlür ḳayg்u (159/69-2 $)^{42}$

Aşağıdaki beyitlerde "gonça" sözcüğü, gibi anlamını veren dèk [< T.] ve yañlı $[<T$.] kelimeleri ile birlikte öncelenmiştir.

Ġonça dèk köñlüm mėniñ gülzār meyli ḳılmaġay

Ġam bile bütken köñül gül-geşt ile açllmag̉ay

${ }^{40}$ Remel-i müsemmen-i mahzûf: Fâ'ilâtün fâ'ilâtün fâ'ilâtün fâ'ilün. "Yay kaşın gibi eğilen zayıf bedenimi mi, yoksa saçın gibi kara talihimi mi diyeyim?»

${ }^{41}$ Müctess-i müsemmen-i mahbûn-1 mahzûf: Mefâ'ilün fe'ilâtün mefâ'ilün fe'ilün. «Kaşında kıvrım, gözünde kin, dudağında bal. Sözünde zehir ama dilinde derman var. Ortalıkta yanına çok varamam, ne yapayım? (Göz) yaşım inci dişinsiz ayrı bir umman denizidir.»

${ }^{42}$ Hezec-i müsemmen-i ahreb: Mef'ûlü mefâ'ilün mef'ûlü mefâ'ilün. «Nereye gitsem sıkıntı yanımda gelir, nereye dönsem karşıma kaygı çıkar.» Diğer örnek: 172/92-1. 
Yoḳtur ol kim gül yüzüñdin ayru baḳsam gül sarı

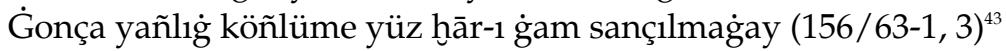

\subsection{Yakın anlamlı sözcükler}

Aşağıdaki örneklerde cân-köñül, gül-gonça, âşık-derdmend sözcükleri mısra başında yer alarak öncelenmiştir, aynı zamanda beyitlerde paralelizm de söz konusudur.

\begin{tabular}{|l|l|l|l|l|}
\hline Cānım & dèk & özge & cān-1 dil-efgār & körmedim \\
\hline Köñlüm & kibi & & köñülni giriftār & tapmadım \\
\hline
\end{tabular}

Cānım dèk özge cān-1 dil-efgār körmedim

Köñlüm kibi köñülni giriftār tapmadım (121/6-1 $)^{44}$

Şu beyitteki gül ile gonça sözcükleriyle paralellik sağlanmaktadır:

\begin{tabular}{|l|l|l|l|l|l|}
\hline Gül cemālın & yapḳan & ol & gülniñ & iki & reyhānıdur \\
\hline Ǵonça sırrın & açḳan & ol & & ikki & leb-i ḩandānıdur \\
\hline
\end{tabular}

Gül cemālıñ yapḳan ol gülniñ iki reyḥānıdur

Ǵonça sırrın açḳan ol ikki leb-i handānıdur (143/44-1 $)^{45}$

\begin{tabular}{|c|c|c|c|c|c|}
\hline ‘Āşıkịi-mèn & ol & kıllur & ag̀yārġa & maḥbūbluḳ & \\
\hline Derdmendī-mèn & velì ol & & özgege & dermān & bèrür \\
\hline
\end{tabular}

'Āşıkị-mèn ol ḳılur ag̉yārg̉a maḥbūbluk

Derdmendī-mèn velì ol özgege dermān bèrür $(139 / 36-2)^{46}$

${ }^{43}$ Remel-i müsemmen-i mahzûf: Fâ'ilâtün fâ'ilâtün fâ'ilâtün fâ'ilün. «Goncaya benzeyen gönlüm gül bahçesine meyletmez, (çünkü) gam (dikeniyle) biten gönül gül görmekle açılmaz. Senin gül yüzünden ayrı gül tarafına baksam o yoktur, gonca gibi gönlüme yüzlerce gam dikeni batmayacak.»

${ }^{44}$ Muzâri'-i müsemmen-i ahreb-i mekfûf-1 mahsûf: Mef'ûlü fâ'ilâtü mefâ'̂̂lü fâ'ilün. «Canım gibi yaralı başka can görmedim, gönlüm gibi tutkun gönül bulmadım.» Diğer örnekler: 121/6-1, 2; 128/18-1, 128/19-2, 184/113-3.

${ }^{45}$ Remel-i müsemmen-i mahzûf: Fâ'ilâtün fâ'ilâtün fâ'ilâtün fâ'ilün. «O gülün gül cemalini örten iki reyhanıdır. Gonca (ağzın) sırrını açan gülen o iki dudağıdır.»

${ }^{46}$ Remel-i müsemmen-i mahzûf: Fâ'ilâtün fâ'ilâtün fâ'ilâtün fâ'ilün. «Âşığı benim, o rakiplere sevgili olur. Dertlisi benim, ama o başkalarına derman verir.» 


\subsection{Karşıt anlamlı sözcükler}

Şu beyitlerde ise anlamca karşıtlık belirten baş-ayak, cefâ vü cevrvefâ vü mihr, kündüz-keçe, men-sen, habîb-rakîb, seyl-ra'd, işret-fürkat, vasl-hecr, visâl-firâk ve bilmedim-bildim sözcükleri öncelenmektedir. İlgili beyitlerdeki paralelizm ise aşağıda tablolarda gösterilmiştir:

Başımġa çıḳtı tütün reşktin ḳara saç dèk

Ayaḳ̣a tüşkeli èy serv-i nāz tā saçıñ (123/10-2) $)^{47}$

\begin{tabular}{|l|l|l|l|l|l|l|l|}
\hline Cefā & vü & cevr & țavrıdın & èrür-sèn & asru & köp & vākııf \\
\hline Vefā & vü & mihr & resmidin & bolur-sèn & asru & köp & gāfil \\
\hline
\end{tabular}

Cefā vü cevr țavrıdın èrür-sèn asru köp vāḳıf

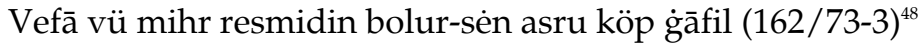

\begin{tabular}{|l|l|l|l|l|l|}
\hline Kündüz & olsa & tüngeçe & aytay mu & bī-pāyān ġamım & \\
\hline Kèçe & bolsa & tañg்a dègrü & & hāal-1 zārımnı mu & dèy \\
\hline
\end{tabular}

Kündüz olsa tüngeçe aytay mu bī-pāyān ġamım

Kèçe bolsa tañg̉a dègrü ḥāl-1 zārımnı mu dèy $(159 / 68-2)^{49}$

Mèniñ köñlümni her dem ag̉rıtıp pervāy ḳılmas-sèn

Sèn èy bì-derd neyley kim köñül derdini bilmey-sèn (168/84-1 $)^{50}$

\begin{tabular}{|l|l|l|l|l|}
\hline Habīib & bolsa èdi & yā & rakịib & ölse èdi \\
\hline Rakīib & ölse èdi & yā & ḥabīb & bolsa èdi \\
\hline
\end{tabular}

${ }^{47}$ Müctess-i müsemmen-i mahbûn-1 maktu': Mefấ'ilün fe'ilâtün mefấ'ilün fa'lün. «Ey naz servisi! Saçın ayağa düştüğünden beri kıskançlıktan kara saç gibi duman başıma çıtı.»

${ }^{48}$ Hezec-i müsemmen-i sâlim: Mefâ'̂̂lün mefấ̂̂lün mefâ'îlün mefâ'îlün. «Eziyet ve sıkıntı tavrını çok iyi bilirsin. Vefa ve sevgi konusunda ise çok aymazsın.» Diğer örnekler: cevr-işve: 164/77-3, vefā-cefā: 144/45-6, 168/84-3, mihr ü vefā-cevr ü cefã: 135/30-3.

${ }^{49}$ Remel-i müsemmen-i mahzûf: Fấilâtün fấilâtün fấilâtün fấilün. «Gündüz olsa geceye dek sonsuz üzüntümü mü, gece olsa tana değin ağlayışımı mı diyeyim?»

${ }^{50}$ Hezec-i müsemmen-i sâlim: Mefấ̂̂lün mefấ̂̂lün mefấ̂̂lün mefấ̂̂lün. «Benim gönlümü her an ağrıtıp çekinmezsin. Ey dertsiz! Sen gönül derdini bilmezsin, ne yapayım?» Diğer örnekler: sẻn dèk-mèn dèk: 133/27-1, sẻndin-mèndin: 154/60-5, farklı beyitte: saña-maña: 148/51-2, 4 . 
Habīb bolsa èdi yā rakịib ölse èdi

Raḳīb ölse èdi yā habīb bolsa èdi (190/123-1)

\begin{tabular}{|l|l|l|l|}
\hline Seyl & èmestür & yėr yüzin tutḳan & közümniñ yaşıdur \\
\hline Ra'd & èmestür & kökke çırmaşķan & köñul efgàānıdur \\
\hline
\end{tabular}

Seyl ėmestür yèr yüzin tutḳan közümniñ yaşıdur

Ra'd èmestür kökke çırmaşḳan köñül efgāānıdur (144/44-4) $)^{52}$

'İşret içre her ḳaçan kim çeng alsañ èlgiñe

Fürḳatıñda ḳalg̉an ègri ḳāmetim yād eylegil (141/40-2) $)^{53}$

\begin{tabular}{|l|l|l|l|}
\hline Vaṣlıdın & ol maña & muhāa & ḳılur \\
\hline Hecridin & mèni & ḩasta-hāāl & ḳılur \\
\hline
\end{tabular}

Vaṣlıdın ol maña muhāl ḳılur

Hecridin mèni ḩasta-ḥāl ḳılur (137/33-1) $)^{54}$

\begin{tabular}{|l|l|l|l|}
\hline Vișālı lezzzetidin & & rūḥ tapmağlık & èrür duşvār \\
\hline Firāḳı şiddetide & yoḳsa & cān bèrmeklik & āsāndur \\
\hline
\end{tabular}

Viṣālı ležżetidin rūḥ tapmag̉lık èrür duşvār

Firāḳı şiddetide yoḳsa cān bèrmeklik āsāndur (148/50-4)

Farklı beyitlerde:

Aldı köñlümni saġındım kim maña dildār èmiş

Bilmedim bu nev' mèndin ol peri bīzār èmiş

${ }^{51}$ Müctess-i müsemmen-i mahbûn-1 mahzûf: Mefâ'ilün fe'ilâtün mefâ'ilün fe'ilün. «Sevgili olsaydı veya rakip ölseydi, rakip ölseydi veya sevgili olsaydı.»

${ }^{52}$ Remel-i müsemmen-i mahzûf: Fâ'ilâtün fâ'ilâtün fâ'ilâtün fâ'ilün. "Yeryüzünü tutan sel değil gözümün yaşıdır. Göğe yükselen şimşek değil gönlümün ahıdır.»

${ }^{53}$ Remel-i müsemmen-i mahzûf: Fâ'ilâtün fâ'ilâtün fâ'ilâtün fâ'ilün. «Eğlencede her ne zaman eline çeng alsan, ayrılığında kalan eğri boyumu an.»

${ }^{54}$ Hafîf-i müseddes-i mahbûn-1 mahzûf: fâ'ilâtün mefâ'ilün fe'ilün. «Kavuşma hakkında bana "Olmaz!" der. Ayrılıktan beni hasta eder.»

${ }^{55}$ Hezec-i müsemmen-i sâlim: Mefâ'îlün mefâ'îlün mefâ'îlün mefâ'îlün. «Kavuşmanın lezzetinden can bulmak zordur, yoksa ayrılığın şiddetiyle can vermek kolaydır.» 
İltifāt ètmes līkin nāzı hayāl eyler ėdim

Ėmdi bildim kim aña mẻndin bu yañlı̀ 'ār ėmiş (152/58-1, 3)

\subsection{Kökteş kelimeler}

Şu beyitlerde ise aynı kökten türemiş olan 'adâvet-'adû $[<$ Ar. '-d-v] ikâmet-makâm [< Ar. k-v-m], keltürmek-kelmek [< T.], tilemek-tilek [< T.], hayât-hayâtsız [< Ar. h-y-y] - [< T.], za'f-za'flig [< Ar. ż-'-f] - [<T.] sözcükleri mısra başında yer alarak öncelenmiştir.

'Adāvet atı muhabbet nişānı ḳalġuça Bābur

'Adū-yı hayl-1 Yezīd ü muhibb-i āl-i 'abādur (172/91-5) ${ }^{57}$

İḳāmet çün-ki ḳıldıñ Bāburā ol ḥūr kūyıda

Maḳāmıñ ravżadın ullı özüñ rıżvāndın artuk-sèn (139/35-5)

Kèltürse yüz belānı oşal bī-vefā maña

Kèlsün eger yüzümni èvürsem belā maña $(130 / 22-1)^{59}$

Tilerim serv-i revānıñ revişin

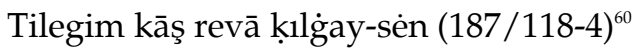

Farklı beyitlerde:

Dẻmeñ oḳını tenımġa belā-yı cān kèldi

Hayātsız bedenımġa oḳı revān kèldi

Hayāt suyını ḳoy kim lebidin aldım kām

Bar èy Hużır ki maña 'ömr-i cāvdān kèldi (157/66-1, 2) ${ }^{61}$

${ }^{56}$ Remel-i müsemmen-i mahzûf: Fâ'ilâtün fâ'ilâtün fâ'ilâtün fâ'ilün. «Gönlümü aldı. Benim sevgilim sandım, o perinin benden böyle usandığını bilmedim. İltifat etmeyişini nazdan sanırdım, böylesi düşünce ayıpmış, şimdi bildim.»

${ }^{57}$ Müctess-i müsemmen-i mahbûn: Mefâ'ilün fe'ilâtün mefâ'ilün fe'ilâtün. «Ey Bâbur! Düşmanlığın adı, muhabbetin izi kaldıkça Yezid'in ordusu düşman, Hz. Muhammed'in ailesi sevgilidir.»

${ }^{58}$ Hezec-i müsemmen-i sâlim: Mefâ'îlün mefâ'îlün mefâ'îlün mefâ'îlün. «Ey Bâbur! O hurinin mahallesinde oturduğundan dolayı makamın ravzadan, kendin de rıdvandan büyüksün.»

${ }^{59}$ Muzâri'-i müsemmen-i ahreb-i mekfûf-1 mahsûf: Mef'ûlü fâ'ilâtü mefâ'îlü fâ'ilün. «O vefasız bana yüzlerce bela getirse, gelsin; eğer yüzümü çevirirsem bela bana gelsin.»

${ }^{60}$ Remel-i müseddes-i mahbûn-1 mahzûf: Fe'ilâtün fe'ilâtün fe'ilün. «Salınan servinin salınmasını dilerim, dileğimi keşke yerine getirsen.» 

Ża'fdın gūyā mẻniñ bu zār cismim nāldur
Kim anıñ şerhịin dèmekte ḩāme tili lāldur
Ża'fllì cismim bile bu nā-tuvān köñlüm ara
Derd bar èrkenge oşbu ègme ḳaddım dāldur (133/26-1, 2) ${ }^{62}$

\subsection{Sevgiliye ait unsurlar}

Klâsik Türk edebiyatının temel tipi sevgiliye ait unsurlar olan kad "boy", leb "dudak", serv "servi, mecazen sevgilinin boyu" gül "mecazen sevgilinin yüzü, yanağı" ve yüz sözcükleri aşağıdaki beyitlerde misra başında yer alarak öncelenmiştir. İlgili beyitlerdeki paralelizm ise yine tablolarla aşağıda gösterilmektedir.

\begin{tabular}{|l|l|l|l|l|}
\hline Kadı & şāh̆-1 gül & dèk & nigārım & ḳanı \\
\hline Lebi & gonça & dèk & gül-'ižārım & ḳanı \\
\hline
\end{tabular}

Kadı şāh-ı gül dèk nigārım ḳanı

Lebi g̉onça dèk gül-'iz̄ārım ḳanı (149/53-1) ${ }^{63}$

\begin{tabular}{|l|l|l|l|l|}
\hline Serv & dèk & ḳaddī fırāḳıda & fiḡānımdur & bülend \\
\hline Gül & kibi & ruhsāri hecride & yaşımdur & lāle-gūn \\
\hline
\end{tabular}

Serv dèk ḳaddi fırāḳıda fiḡānımdur bülend

Gül kibi ruhsārī hecride yaşımdur lāle-gūn (145/146-6) ${ }^{64}$

\begin{tabular}{|l|l|l|l|}
\hline Yüzüñ & èy & serv & cānım gülşeniniñ tāza gülzārı \\
\hline Kadıñ & èy & gül & hạayātım bāġınıñ serv-i revānıdur \\
\hline
\end{tabular}

${ }^{61}$ Müctess-i müsemmen-i mahbûn-1 maktu': Mefâ'ilün fe'ilâtün mefâ'ilün fa'lün. «Tenimdeki okuna "Can belası geldi." demeyin. Hayatsız bedenime oku can getirdi. Bengisuyu bırak, dudağından tat aldım. Ey Hızır! Git, bana sonsuz ömür geldi.»

${ }^{62}$ Remel-i müsemmen-i mahzûf: Fâ'ilâtün fâ'ilâtün fâ'ilâtün fâ'ilün. «Benim bu ince bedenim zayıflıktan sanki bir kamıştır/naydır. Onu şerh etmede kalemin dili tutulmuştur. Zayıf bedenimle hassas gönlüm arasında dert var, işte bu eğik belim buna daldir/delildir.»

${ }^{63}$ Mütekârib-i müsemmen-i mahzûf: Fe'ûlün fe'ûlün fe'ûlün fe'al. «Boyu gül fidanına benzeyen sevgilim hani? Dudağı goncaya benzeyen gül yanaklım hani?»

${ }^{64}$ Remel-i müsemmen-i mahzûf: Fâ'ilâtün fâ'ilâtün fâ'ilâtün fâ'ilün. "Servi gibi bir boyun ayrılığından feryadım yüksek, gül gibi bir yanağın uzağında göz yaşım kızıl renktir.» 
Yüzüñ ėy serv cānım gülşeniniñ tāze gülzārı

Kadıñ èy gül ḥayātım bāg̀ınıñ serv-i revānıdur (161/71-4)

\section{Yüklem öncelemeleri}

Bâbur divanında eylem-yüklem öncelemeleri ile de karşılaşılmaktadır, ancak sözcük öncelemesine göre yüklem öncelemesi daha azdır. Divanda boldı köñlüm, bolgay mu, gâfil olma ve ne bilgey-sen yüklemleri öncelenmektedir.

Boldı köñlüm

Tā hayāl-i 'ārıżıñ tüşti köñülge èy ḳuyaş

Boldı köñlüm bir yanar ot u süñeklerim otun

Boldı köñümde girih hasret anıñ tar aġzıdın

Bar meger cismim mėniñ tār u köñül anda tügün $(145 / 46-3,4)^{66}$

Bolgay mu

Çıksa ḳuyaş felekke sẻn atḳa çıḳḳanıñ dẻk

Bolgay mu ol sèniñ dèk ol perr-i tevseniñ dèk

Ger sīm-berg-i gülni ḳılsa libās özige

Bolġay mu èy gül-endām köñlek bile teniñ dèk $(153 / 59-1,3)^{67}$

Ġāfil olma

Aşağıdaki beyitlerde "Gâfil olma" tümcesi öncelenmiştir. 1. beyitteki sāḳi ... bāḳī; 2 . beyitteki devlette ... mihnette ... elbette ... iste sözcükleri ile iç kafiye yapılarak ahenk sağlanmaktadır.

Gāfil olma èy sākīi gül çaġın ganīmet bil

Vaḳt-ı 'ayş èrür bāḳi al çaġır kètür bat tut

${ }^{65}$ Hezec-i müsemmen-i sâlim: Mefâ'îlün mefâ'îlün mefâ'îlün mefâ'̂̂lün. «Ey servi! Senin yüzün can bahçemin güllüğü, boyun hayat bağımın salınan servisidir.»

${ }^{66}$ Remel-i müsemmen-i mahzûf: Fâ'ilâtün fâ'ilâtün fâ'ilâtün fâ'ilün. «Ey güneş! Yanağının hayali gönlüme düştüğünden beri gönlüm yanan bir ateş, kemiklerim odundur. Onun dar ağzı yüzünden gönlümde hasret düğüm oldu. Meğer benim dar bir cismim varmış, gönül de ondaki düğümmüş.»

${ }^{67}$ Muzâri'-i müsemmen-i ahreb: Mef'ûlü fâ'ilâtün mef'ûlü fâ'ilâtün. «Senin ata binişin gibi güneş feleğe çıksa o senin gibi ve senin dik kanadın gibi olabilir mi? Ey gül vücut? Eğer gülün gümüş yaprağını kendine elbise etse senin gömlekli tenin gibi olabilir mi?» 
Gāfil olma devlette özni salma miḥnette

Tèñri bèrür elbette devlet iste himmet tut $(178 / 103-1,3)^{68}$

Nè bilgey-sèn

Nè bilgey-sèn mėniñ derd ü gamım her sā'at $u$ her dem

Kim hüün ösrüklügidin āy u yıl èy āy ayılmay-sèn

Katılma 'sşk ehli ḩālin çü bilmes-sẻn maña èy şūh

Nè bilgey-sèn ki hergiz bu cemāatḳa ḳatılmay-sẻn $(168 / 84-2,4)^{69}$

\section{Teklif}

Bâbur divanında tespit edilmiş öncelemeler, şairin üslubunu oluşturan unsurlardan biri olarak karşımızda durmaktadır. Buna göre Bâbur'un şiir stilinde öncelemenin önemli bir düzenleme biçimi olduğu söylenebilir. Yukarıdaki üslup incelemesinden hareketle şairin asıl metnine ulaşmada öncelemelerden de yararlanılabilir. Divandaki 111. gazelin matla beyti; 2., 3. ve 6 . beyitlerinin ikinci misraları "ol" sözcüğü ile başlamaktadır. Nüsha farkı olarak belirtilmemekle birlikte 4 . ve 5 . beyitlerinin 2. mısraları da aynı şekilde başlayabilir ve gazel aşağıdaki gibi olabilir:

\section{Gazel $^{70}$}

Ol 'ahd ile peymān ḳanı èy yār nẻ boldı

Ol luṭf ile iḥsān ḳanı èy yār nẻ boldı

Kèttim ėşigiñdin mẻni ḥayrān dẻmediñ hịç

Ol tèlbe-i ḥayrān ḳanı èy yār nẻ boldı

${ }^{68}$ Hezec-i müsemmen-i sâlim-i eşter: Fâ'ilün mefâ'îlün fâ'ilün mefâ'îlün. «Ey saki! Gül çağını ganimet bil, gafil olma. Eylence vakti gecikti, kadeh al, getir, çabuk uzat. Devletten gafil olma, kendini üzüntüye salma, devlet iste, himmet bul, elbette tanrı verir.»

${ }^{69}$ Hezec-i müsemmen-i sâlim: Mefâ'îlün mefâ'îlün mefâ'îlün mefâ'îlün. " Ey ay! Güzelliğinin sarhoşluğundan aylarca yıllarca ayılmazsın, öyleyse her an ve her saat olan benim derdimin üzüntüsünü ne bileceksin?»

${ }^{70}$ Hezec-i müsemmen-i ahreb-i mekfûf-1 mahzûf: Mef'ûlü mefâ'îlü mefâ'îlü fe'ûlün. «Ey yar! O sözle yemin hani ne oldu? O lütuf ile bağış hani ne oldu? Eşiğinden ayrıldım, "O deli âşık hani?" demedin hiç, ne oldu? Halkın arasında yüzünü göstererek lütfederdin, o gösterdiğin lütuf hani ne oldu? Gönül isteyerek senin tarafına vardı, şimdi bulamam. O senin tarafına varan hani ne oldu? Sözün canıma devaydı, söylemedin ah. O derde derman hani ne oldu? Sözleşmemiz böyle miydi? Bâbur'u unuttun. O söz ile yemin hani ne oldu?» 
Yüz körsetiben èl içide luṭf èter èrdiñ

Ol luṭf-ı numāyān ḳanı èy yār nẻ boldı

Sèniñ sarı bardı köñül istep tapa alman

[Ol] sèn\{iñ \} sarı barġan ḳanı èy yār nè boldı

Cānımġa devā sözüñ èdi sözlemediñ āh

[Ol] \{cān\} derdig̀a dermān ḳanı èy yār nẻ boldı

Mundak mu èdi 'ahd ki Bāburnı unuttuñ

Ol 'ahd ile peymān ḳanı èy yār nẻ boldı (183/111)

\section{Sonuç}

Bâbur divanında stilistik bir özellik olarak mèn, sèn, ol, biz ve bu zamirleri; kim, kaysı, kaysı bir, nėçe, kanı soru sözcükleri; eger, gehî, hem, nè, yene bir bağlamları; ayş, dehr, feryâd, gül, hoş ol, hüsn ehli, 1şk, kadd, gönüul, köz, köz yaşı, kuyaş, nėçe, tarahhum, yaglıg ve yaz faslı sözcükleri; cinaslı, anlamdaş, yakın ve karşıt anlamlı, kökteş sözcükler; klasik şiirde sevgili tipine ait unsurları ifade eden sözcükler ve boldı köñlüm, bolgay mu, gâfil olma, ne bilgey-sen yüklemleri öncelenmekte, kimi zaman öncelemelerle birlikte sözcüklerin sıralanışı açısından paralelizm oluşturulmaktadır.

\section{Kaynaklar}

AKAY, Hasan (1998), Cenab Şahabeddin'in Şiirleri Üzerinde Stilistik Bir Araştırma (Şiir Tahlilleri), İstanbul: Kitabevi yayını, 587 s.

ARAT, Reşid Rahmeti (1986), Eski Türk Şiiri, 2. bs. Ankara: Türk Tarih Kurumu Yayını, XIII+506 s.

CoşKun, Menderes (2007), Sözün Büyüsü Edebi Sanatlar (Edebi Sanatlar Üzerine Mukayeseli Bir Araştırma), İstanbul: Dergâh yayını, 368 s.

Díç̧iN, Cem (2008), “Stilistik Açıdan 'Öncelemeler' ve Fuzuli'nin Şiirlerinde Yüklem Öncelemesi”, Divan Edebiyatı Araştırmaları Dergisi, sy. 1, Güz, s. 41-94.

KurNAZ, Cemal (1993), Ahmet Talât Onay: Eski Türk Edebiyatında Mazmunlar ve Izahı, Ankara: Türkiye Diyanet Vakfı yayını, IXV+500 s.

ÖZTÜRK, Mürsel ve ÖRS Derya (2000), Mütercim Âsım Efendi: Burhân-ı Katı, Ankara: Türk Dil Kurumu yayını, XLIX+1197 s.

YÜCEL, Bilal (1995), Babür Divanı (Gramer-Metin-Sözlük-Tıpkıbasım), Ankara: AKM yayını, xii+575 s. 